\title{
Describing condition-specific determinants of competition in boreal and sub-boreal mixedwood stands
}

\author{
by D. Scott Green ${ }^{1}$
}

\begin{abstract}
There is a growing economic and ecological incentive in developing best-management practices for broadleaf-conifer mixedwood stands in boreal and sub-boreal regions of Western Canada. Current free-growing guidelines employed in these areas appear to be poor predictors of interactions between primary growth determinants and environmental conditions in these complex stands. Densitydependent relations between broadleaf and conifer components in mixedwood stands may vary across a range of conditions due to interactions discussed in this paper between primary growth determinants (i.e., light limitations, edaphic limitations and speciesspecific traits) and local environment. Clarifying these interactions will promote the development of adaptable tools that can be used to develop context-specific mixedwood management strategies.
\end{abstract}

Key words: mixedwood management, free-growing guidelines, boreal, sub-boreal, density-dependent competition

Il y a de plus en plus d'incitations économiques et écologiques reliées au développement des pratiques pour un meilleur aménagement des peuplements mélangés de feuillus et de conifères dans les zones boréales et sous-boréales de l'Ouest canadien. Les directives actuelles de régénération libre de croître utilisées dans ces zones semblent être de piètres indicateurs des interactions entre les facteurs primaires de croissance et les conditions environnementales au sein de ces peuplements complexes. Les relations basées sur la densité entre les composantes feuillues et résineuses des peuplements mélangés peuvent varier selon un ensemble de conditions découlant des interactions discutées dans cet article entre les facteurs primaires de croissance (par ex., limites associées à l'ensoleillement, limites découlant du sol et les caractéristiques spécifiques à l'espèce) et l'environnement local. Une meilleure connaissance de ces interactions permettra le développement d'outils versatiles qui pourront être utilisés pour élaborer des stratégies d'aménagement des forêts mixtes spécifiques au contexte.

Mots-clés : aménagement des forêts mixtes, directives de régénération libre de croître, zone boréale, zone sous-boréale, compétition dépendante de la densité

\section{Introduction}

In recent decades, the interest in managing broadleaf-conifer mixed tree species (hereafter, mixedwood) stands has grown with an improved understanding of their potential economic benefits (Kelty 1992, Sachs 1996, Comeau et al. 1999, Steele et al. 2001, Valkonen and Valsta 2001) and ecological benefits (Holbo et al. 1985, Mielikainen 1985, Morrison et al. 1988, Stathers 1989, Morrison et al. 1991, Watt 1992, Enns et al. 1993, McComb 1994, Taylor et al. 1994, Wang et al. 1995, Prescott et al. 2000). However, uncertainty about best-management practices in mixedwood stands has often been expressed in a default strategy of minimizing the incidence and growth of competing broadleaf tree species through intensive and expensive practices (even though management guidelines permit the presence of broadleaf competitors, see Simard 1996).

The development of effective management practices in boreal and sub-boreal mixedwood forests of Western Canada must incorporate the greater inherent complexity of broadleafconifer mixtures relative to single-species or mixed-species conifer forests (Simard 1996). Broadleaf and evergreen tree species have distinct growth patterns that manifest themselves following the initiation of mixedwood stands. Broadleaf species (such as Populus tremuloides Michx. [trembling aspen] and Betula papyrifera Marsh. [paper birch]) tend to grow faster than their conifer associates, commonly spruce and fir in boreal and sub-boreal regions (Simard 1990, 1996; Comeau 1996;

\footnotetext{
${ }^{1}$ Assistant Professor, Ecosystem Science and Management, University of Northern British Columbia, 3333 University Way, Prince George, British Columbia V2N 4Z9. E-mail: greens@unbc.ca
}

Peterson and Peterson 1996, Comeau et al. 1999, Yang et al. 2003), creating a high degree of structural complexity (i.e., stratified stands). Consequently, conifers are often relegated to understory conditions during early mixedwood stand development (Drew 1988, Valkonen and Valsta 2001).

While the successional trajectories of such complex stands remain unclear, it is well established that the regeneration and

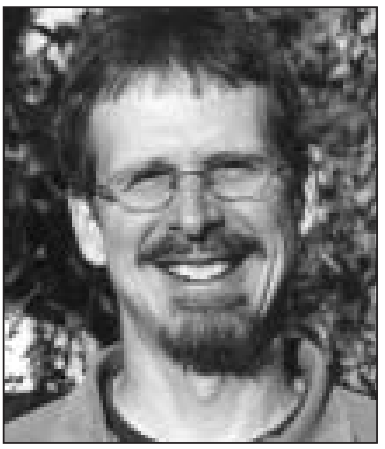

D. Scott G reen growth potential of understory conifer crop trees in mixedwood stands is correlated to the density of competing broadleaf trees. These relations have been characterized in numerous mixedwood stands (e.g., Lieffers and Stadt 1994, Comeau et al. 1999, Messier et al. 1999, Jobidon 2000, Brandeis et al. 2001, Prévost and Pothier 2003, Valkonen and Ruuska 2003). Current management guidelines in Alberta and British Columbia, which are used to describe the "competition neighbourhood" around conifer crop trees in mixedwood stands (i.e., freegrowing stocking standards), rely on distance-dependent relations confined to a small area around crop trees (MacIsaac and Navratil 1996, Lieffers et al. 2002). However, Lieffers et al. (2002) found that free-growing stocking standards failed to reasonably characterize light competition between broadleaf and conifer components in boreal mixedwood stands and that adequate sampling using current approaches would be operationally prohibitive. 
In fact, current free-growing standards employed in developing mixedwood stands may be too coarse-filtered to adequately describe competitive responses to a number of important growth determinants (in particular, light limitations, edaphic limitations and species-specific interactions.) and their interactions with environmental conditions (Green In Review). ${ }^{2}$ This paper reviews current knowledge about such key densitydependent determinants of competitive relations among mixedwood components and the sensitivity of these factors to changes in environmental conditions in an effort to identify critical knowledge gaps that need to be addressed in the development of appropriate mixedwood management tools.

\section{Light Limitations}

Numerous researchers have suggested that competitive interactions between broadleaf and conifer components in mixedwood stands (at least in stratified stands) primarily reflect light limitations imposed by overstory broadleaf trees (e.g., Brand 1986, Simard 1996, Tanner et al. 1996, Comeau et al. 1999, Lieffers et al. 2002, Wang and Kimmins 2002). Further, light conditions mediated by both spatial and temporal factors may influence density-dependent relations between mixedwood components.

The spatial separation of broadleaf and conifer trees in stratified mixedwood stands results in inverse relations between broadleaf density and light interception (which is proportionally related to volume and biomass production, see Monteith 1972, Green 1998, Green et al. 2003) for mixedwood components. Light interception in the overstory increases with broadleaf stem density (or basal area), while light interception in the understory decreases (Comeau 2001, Comeau and Heineman 2003). Consequently, conifer survival, height growth and stemvolume increments in the understory have been shown to be negatively correlated with broadleaf stem density or basal area (Lieffers and Stadt 1994, Man and Lieffers 1997b, Jobidon 2000, Comeau 2001, Lieffers et al. 2002). Minimum understory light thresholds for conifer survival may be exceeded in dense broadleaf stands (Pinno et al. 2001) with light levels observed as low as $2 \%$ full light (Lieffers et al. 2002), which can result in high mortality among the most shade-tolerant conifers.

While the observed relations in mixedwood stands between overstory structure and understory light availability suggests a means to model light dynamics in mixedwood stands for management applications (Comeau 2001, Lieffers et al. 2002), there remains much uncertainty about how to operationally achieve and maintain target light levels for acceptable survival and growth of conifer crop trees. The spatial distribution of overstory broadleaf trees, for instance, creates considerable heterogeneity in understory light environments. Clumpiness in broadleaf tree patterns affects the amount, orientation and spatial distribution of leaf area, all of which have a strong bearing on the light environment and conifer growth in the understory (Pinno et al. 2001, Lieffers et al. 2002).

The temporal (phenological) separation of light utilization periods between deciduous broadleaf and evergreen conifer habits may be an important determinant of density-dependent relations in mixedwood stands (Man and Lieffers 1999).

\footnotetext{
${ }^{2}$ Consideration of these factors in this paper will be limited to stratified mixedwood stands to minimize the potential complexity of the issues.
}

Observations of photosynthetic productivity of understory conifer trees during the spring (and to a lesser degree autumn) broadleaf leafless periods suggest that these high-light windows may constitute an important ecological strategy to enhance the survival, growth and annual carbon balance of understory conifer trees (Baldocchi et al. 1984; Constabel and Lieffers 1996; Mielikainen 1996; Man and Lieffers 1997a, 1997b, 1999; Gill et al. 1998).

However, the relative importance of temporal separation in light utilization for understory conifer trees in mixedwood stands may vary with broadleaf density. High-light windows may be particularly important for conifer survival and growth at moderate to high broadleaf densities. In a pilot study looking at the growth of shade-tolerant subalpine fir (Abies lasiocarpa [Hook.] Nutt.) saplings under variable densities of paper birch cover in central British Columbia (Fig. 1, unpublished dataD.S. Green 2002 [see Comeau et al. 1998 for a description of the study site and mixedwood stand structure]), the spring highlight window provided little apparent benefit at the endpoints of overstory broadleaf stem densities (i.e., high and low). Bi-weekly measurements of radial stem growth (using highresolution band dendrometers) and relative photosynthetic photon flux density (PPFD) (i.e., the ratio of understory PPFD and ambient PPFD taken under cloudy conditions just above each target fir sapling) for understory fir saplings permitted an assessment of temporal growth trends during the deciduous leafless period. No measurable stem growth occurred during the spring high-light (leafless) window below a light threshold of about $60 \%$ full light, which corresponded to a light level of about $7 \%$ full light during mid-summer (see Fig. 1D). At such high cover densities, shading by broadleaf branches may sufficiently restrict light levels in the understory during the deciduous leafless period to create secondary limitations (e.g., delayed snowmelt and near-frozen soils, which can hinder biophysical processes such as root conductance of water; see Teskey et al. 1984, Jurik et al. 1988, Man and Lieffers 1997a). As broadleaf densities decreased below the highest levels observed in the pilot study (i.e., increasing understory light availability), conifer saplings utilized increasing portions of the spring leafless period for measurable stem growth (see Fig. 1C). At low broadleaf densities in this pilot study, stem growth trends during the leafless period were similar to trees growing under full light (see Fig. 1B). At these low levels of cover, understory light-availability differences between the leafless and leafed period may not be significant in terms of photosynthetic production or secondary limitations.

\section{Edaphic Limitations}

While generally considered to be less limiting than light in mixedwood stands, competition for edaphic resources may play an important role in relations between broadleaf and conifer components (Comeau et al. 1999, Man and Lieffers 1999). As with light limitations, density-dependent relations in mixedwood stands may be influenced by edaphic conditions mediated by both spatial and temporal factors. Some studies suggest that broadleaf and conifer species may exploit different edaphic niches in mixedwood stands due to a spatial separation in rooting zones (Laitakari 1934, Strong and La Roi 1983, Kabzems and Lousier 1992, Mielikainen 1996, Man and Lieffers 1999). While the adaptive importance of such a spatial separation is 


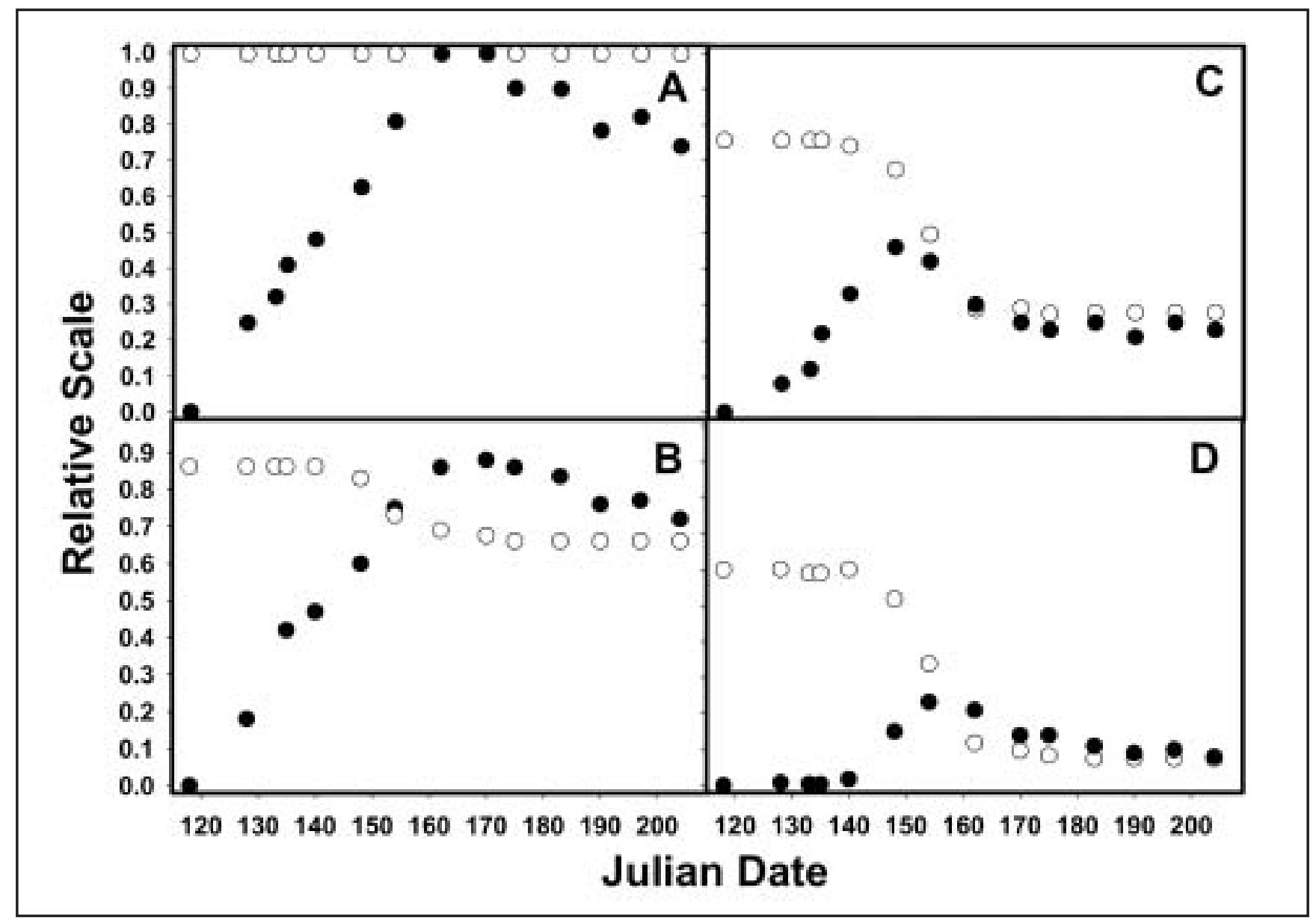

Fig 1: Transmittance of photosynthetically active radiation as a fraction of full light (0.0-1.0 on Relative Scale; open circles) and relative stemwood production (0.0-1.0 on Relative Scale; filled circles) by Julian date for subalpine fir (Abies lasiocarpa [Hook.] Nutt.) saplings growing under variable densities of paper birch (Betula papyrifera Marsh.) cover at the Spey Creek research site (central B.C. - N 53 54' 882, W $122^{\circ} 21^{\prime} 167$ ) during the growing season of 2002. Relative Stemwood Production was scaled to the peak growth of the fastest growing tree (1A). Figures show trends typical under no paper birch cover (A), under low-density paper birch cover (B), under medium-density paper birch cover (C) and under high-density paper birch cover (D).

not clearly understood, the potential benefits will likely increase with stand density as competition for edaphic resources intensifies and as biophysical processes influence important factors such as soil temperature and nutrient mineralization.

The temporal separation of light utilization periods between deciduous and evergreen habits should also influence competition for edaphic resources in mixedwood stands. The reduced demand on edaphic resources by broadleaf trees during their leafless periods should help to sustain the potentially high photosynthetic rates of understory conifers given the enhanced light availability at these times (particularly in the spring, due to the longer days and higher solar angles relative to fall leafless periods) (see Man and Lieffers 1997b). The importance of temporal separation in leafing habits on the availability of edaphic resource for understory conifers may vary with broadleaf density in a manner similar to that described for light.

The potential exploitation of different edaphic and light niches (spatial and temporal) may partly explain the observation that mixedwood stands may be more productive than singlespecies stands (Kelty 1992, Simard 1996, Man and Lieffers 1999).

\section{Species-Specific Interactions}

Density-dependent relations in mixedwood stands may vary due to species-specific interactions between and within functional groups (i.e., deciduous broadleaf vs. evergreen coniferous). Broadleaf species may differ in their light interception potential on a given site and/or in relations between light interception and stand traits such as basal area or stand density. For instance, light measurements taken in the understories of boreal mixedwood stands of trembling aspen or paper birch of variable densities indicated dramatically different relations between light availability and stand basal area (unpublished data P.G. Comeau), with birch attenuating considerably more light at a given basal area (about $88 \%$ vs. $50 \%$ full light at $10 \mathrm{~m}^{2}$ ha ${ }^{1}$ basal area for birch and aspen, respectively) (also see Comeau 2001, Comeau and Heineman 2003). Additionally, broadleaf 
species may vary in the phenology of leaf out and senescence, resulting in differences in the effective period of temporal separation between deciduous and evergreen mixedwood species. The author is not aware of any studies that have examined phenological differences among deciduous mixedwood species. However, during the spring of 2002 and 2003, such differences were observed at the Spey Creek research site (central B.C.) with trembling aspen leafing out about a week before paper birch, which could effectively reduce the spring high-light window for conifer photosynthetic production in aspendominated mixedwood stands. Interactions between light absorption potential at a given basal area and phenology (i.e., timing of leaf out/leaf drop) in different broadleaf species could either increase species distinctions through additive effects (e.g., lower light attenuation at a given basal area associated with later leaf out) or mute species distinctions through compensating tradeoffs (e.g., lower light attenuation at a given basal area associated with earlier leaf out).

Understory conifer species appear to differ in the minimum light thresholds at which survival and growth are severely curtailed (Kobe 1996, MacIssac and Navratil 1996, Simard 1996, Kobe and Coates 1997, Wright et al. 1998, Lieffers et al. 2002). Stewart et al. (2001) found that white spruce (Picea glau$c a$ [Moench] Voss) survival in boreal mixedwood stands decreased rapidly below about $10 \%$ of full light, while Lieffers and Stadt (1994) identified 8\% full light as a minimum light level. Reported observations suggest that minimum light levels vary among other western boreal conifers, including $4 \%$ full light for lodgepole pine (Pinus contorta Dougl. ex Loud var. latifolia Engelm.) (Messier 1996), 1\% full light for subalpine fir (Klinka et al. 1992) and 2.5\% full light for balsam fir (Abies balsamea [L.] Mill.) (Parent and Messier 1995).

Further, intra-species variability in reported minimum light thresholds suggests different responses among geographically distinct populations and/or under different environmental conditions. For example, Eis (1970) found that the critical light threshold for white spruce survival in central B.C. (about $15 \%$ full light) was nearly twice that observed in boreal forests by Lieffers and Stadt (1994). Additionally, Awada and Redmann (2000) reported considerable variation in mortality at low light levels among different populations of white spruce from western and central Canada.

Light requirements for potential growth of conifer seedlings and saplings may also vary among species and conditions. Peak height growth for some boreal conifers (e.g., white spruce and balsam fir) has been shown by some studies to occur between 40-60\% full light (Shirley 1945, Logan 1969, Lieffers and Stadt 1994, Comeau 2001), while Jobidon (2000) found that height increments for white spruce increased all the way to full sun. Peak stem radial and/or volume growth among many boreal and western conifers appears to occur near full light (Eis 1967, Logan 1969, Lieffers and Stadt 1994, Wright et al. 1998, Jobidon 2000, Comeau 2001). However, stem radial-growth trajectories in response to light availability differ among ecologically distinct conifer species (Wright et al. 1998). Conversely, some tree species may achieve peak radial growth under shading cover. Logan (1969) found that stem volume production for shade-tolerant balsam fir was greater at $45 \%$ than at $100 \%$ sunlight. Further, the growth responses of distinct tree species to light availability may vary among environments (Wright et al. 1998), as was noted previously for seedling/sapling responses to minimum light thresholds. Consequently, conifer species appear to differ in their capacity to tolerate broadleaf cover, and some environmental factors appear to influence the relationship.

\section{Influence of Environmental Factors in Density- Dependent Mixedwood Relations}

Density-dependent growth relations between broadleaf and conifer components in mixedwood stands may vary moving across primary environmental gradients toward harsher conditions (e.g., higher elevation and/or latitude; steeper, more northerly slope aspect; increased continentality) due to interactions between local environment and light limitations, edaphic limitations and/or species-specific traits (Green In Review).

Cold soil and air temperatures, which tend to be more prevalent with increasing elevation/latitude and on northerly slope aspects in northern ecosystems, are known to be key limiting factors in tree growth and reproduction (Tryon and Chapin 1983, Van Cleve et al. 1983, Bonan 1992, Navratil 1996, Loehle 1998, Landhäusser et al. 2001). The growth responses of trees to thermal conditions may differ markedly between broadleaf and conifer species, altering their relative dominance in mixedwood stands across environmental gradients (Van Cleve et al. 1983, Landhäusser et al. 2001, Landhäusser et al. 2003). Landhäusser et al. (2001) found strong positive relations between soil temperature $\left(5-25^{\circ} \mathrm{C}\right)$ and numerous growth characteristics (including whole-plant growth, leaf production, root production, net photosynthesis and stomatal conductance) for trembling aspen seedlings. These general trends have been confirmed for trembling aspen and Populus balsamifera $\mathrm{L}$. [balsam poplar] by other studies (Tryon and Chapin 1983, Landhäusser et al. 1996, Landhäusser and Lieffers 1998, Landhäusser et al. 2003). Conversely, Landhäusser et al. $(2001,2003)$ observed slight or no changes in key growth characteristics with increasing soil temperature for white spruce seedlings. Other studies have shown a similar insensitivity to soil temperature for other spruce species, including $P$. engelmannii Parry ex. Engelm. [Engelmann spruce] (Day et al. 1990), P. sitchensis (Bong.) Carr. [sitka spruce] (Turner and Jarvis 1975) and P. mariana (Mill.) B.S.P. [black spruce] (Tryon and Chapin 1983). Further, a low sensitivity to cold soil temperatures may be common among a range of western and boreal conifers. Huxman et al. (2003) observed relatively high carbon uptake rates in subalpine conifer forests (i.e., lodgepole pine, Engelmann spruce and subalpine fir) during periods of depressed soil temperatures in the early growing season.

Additionally, several studies suggest that key mixedwood conifer species are relatively tolerant of near-freezing air temperatures. Studies have shown a relatively flat photosynthetic response to air temperatures between 5 and $15^{\circ} \mathrm{C}$ for lodgepole pine, subalpine fir and Engelmann spruce (Huxman et al. 2003) and between 10 and $25^{\circ} \mathrm{C}$ for Engelmann spruce (DeLucia and Smith 1987). Man and Lieffers (1997b) found a similar photosynthetic insensitivity for white spruce between 5 and $25^{\circ} \mathrm{C}$ in the spring and fall, when light is most abundant in understory. During the summer, photosynthesis at saturating irradiance increased with temperature, but there was little difference at lower light levels (e.g., below $150 \mu$ mol PAR, which would be common in mixedwood understories at moderate broadleaf densities - see Constabel and Lieffers 1996). Subfreezing air temperatures during the growing season are known to impede photosynthesis in trees (Öquist 1983, Man and 
Lieffers 1997b, Lamontagne et al. 1998, Krasowski and Simpson 2001), but again, some evidence suggests that conifers may be less sensitive than deciduous species. At sub-freezing air temperatures, Lamontagne et al. (1998) found that black spruce and jack pine (Pinus banksiana Lamb.) were less sensitive to photosynthetic inhibition and less prone to irreversible damage than trembling aspen. Combined, these studies suggest a convergence in growth indicators and determinants between a variety of broadleaf and conifer species as soil and air temperatures decrease in mixedwood stands due to increasing environmental harshness.

Such distinct responses to temperature between broadleaf and conifer species could alter the role of edaphic limitations, light limitations and species-specific interactions across the range of conditions in which mixedwood stands occur. Consequently, density-dependent relations in mixedwood stands may be quite condition- or site-specific (Green In Review). Edaphic limitations on colder sites would likely change the competitive dynamics between components in mixedwood stands compared to warmer sites, as growth characteristics (and presumably, demand for edaphic resources) among broadleaf and conifer species appear to be more similar on cold sites. In boreal regions, for instance, thick organic layers can limit soil warming (Viereck 1970, Navratil 1996, Landhäusser et al. 2003), which may favour conifers once soils thaw in spring. At high stand densities, where competition for edaphic resources is likely greatest, the shift in stand dynamics among broadleaf and conifer species between warm and cold sites should be most evident.

Light limitations on colder sites may also create different competitive dynamics between broadleaf and conifer species in mixedwood stands compared to warmer sites. As average conditions become colder (or otherwise harsher), the leafarea potential on a site tends to diminish (Waring and Schlesinger 1985, Skre 1993, Constabel and Lieffers 1996, Kabzems and Garcia 2004). A reduction in broadleaf light interception on cold sites should create more favourable light conditions in the understory for less cold-sensitive conifer species. The actual capacity of conifers to exploit better light environments on cold sites may depend upon species-specific factors, as various conifers demonstrate unique adaptation to different environmental stresses that may be associated with increased radiation loads (e.g., water stress; see Man and Lieffers 1997a).

Additionally, the importance of temporal separation in light utilization between deciduous and evergreen habits in mixedwood stands may vary between warm and cold sites. Delays in leaf flush or advances in leaf drop among broadleaf species on cold sites (e.g., at high elevations/latitudes and on north-facing slopes) due to extended periods of depressed air/soil temperatures in the early or late growing season spring (Myking and Heide 1995) may further increase the high-light growth opportunity for conifer species suited to cold conditions.

However, temperature likely interacts with other climate factors (e.g., moisture availability) to determine densitydependent relations (Chen et al. 2002). In wetter regions, climate conditions at higher elevations and latitudes may considerably extend the period of snowcover in spring, decreasing the effective high-light period for understory conifers. In drier, regions (e.g., more continental), early snow-free conditions may occur even at higher broadleaf densities, effectively increasing the high-light period for understory conifers once the soils have thawed. Similarly, slope aspect may interact with latitude, elevation, and continentality, diminishing the importance of temporal separation in high latitude/elevation and high snowfall areas where snowcover would tend to persist on northern slope aspects.

Finally, environmental harshness may alter relations between broadleaf and conifer species during the initiation of mixedwood stands. For example, Navratil (1996) found that aspen suckering decreased in cold soils, potentially diminishing the early dominance of broadleaf species in mixed stands in harsher environments.

\section{Conclusions}

Given the considerable uncertainty regarding the conditionspecific determinants of density-dependent relations and succession in mixedwood stands, the development of spatially explicit management tools is paramount (Chertov et al. 2003, Harper and Kabzems 2003). Current free-growing guidelines for mixedwoods in Alberta and British Columbia appear to be too coarse-filtered to predict the relative importance of key growth determinants and environmental factors across the wide range of conditions in which mixedwood stands are found. Future research must clarify the level of spatial detail required to predict optimal broadleaf densities across a diverse landscape, which remains a significant knowledge gap. It is entirely possible that mixedwood stands in close proximity may vary considerably in the competitive relations among broadleaf and conifer components due to large differences in conditions mediated by factors like elevation and slope aspect (Green In Review). And, the next generation of stand models and management standards must give attention to such important factors.

\section{References}

Awada, T. and R.E. Redmann. 2000. Acclimation to light in planted and naturally regenerated populations of white spruce seedlings. Can. J. Bot. 78: 1495-1504.

Baldocchi, D., B. Hutchinson, D. Matt and R. McMillen. 1984. Seasonal variations in the radiation regime within an oak-hickory forest. Ag. For. Meteorol. 33: 177-191.

Bonan, G.B. 1992. Soil temperature as an ecological factor in boreal forests. In H.H. Shugart, R. Leemans and G.B. Bonan (eds.). System analysis of the global boreal forest. pp. 126-143. Cambridge Press, Cambridge, U.K.

Brand, D.G. 1986. A competition index for predicting the vigour of planted Douglas-fir in southwestern British Columbia. Can. J. For. Res. 16:23-29.

Brandeis, T.J., M. Newton and E. Cole. 2001. A comparison of overstory density measures for describing understory conifer growth. For. Ecol. Man. 152: 149-157.

Chen, H.Y.H., P.V. Krestov and K. Klinka. 2002. Trembling aspen site index in relation to environmental measures of site quality at two spatial scales. Can. J. For. Res. 32: 112-119.

Chertov, O., A. Komarov, J. Kolström, S. Pitkänen, H. Strandman, S. Zudin and S. Kellomäki. 2003. Modelling the long-term dynamics of populations and communities of trees in boreal forests based on competition for light and nitrogen. For. Ecol. Man. 176: 355-369. Comeau, P.G. 1996. Why Mixedwoods? In P.G. Comeau and K.D. Thomas (eds.). Silviculture of temperate and boreal broadleaf-conifer mixtures. pp. 1-7. B.C. Ministry of Forests, Research Program, Victoria, B.C. Land Management Handbook \#36.

Comeau, P.G. 2001. Relationship between stand parameters and understorey light in boreal aspen stands. B.C. J. Ecosys. Man. 1: 1-8.

Comeau, P.G., F. Gendron and T. Letchford. 1998. A comparison of several methods of estimating light under a paper birch mixedwood stand. Can. J. For. Res. 28: 1843-1850. 
Comeau, P.G. and J.L. Heineman. 2003. Predicting understory light microclimate from stand parameters in young paper birch (Betula papyrifera Marsh.) stands. For. Ecol. Man. 180: 303-315.

Comeau, P.G., J. Wang, T. Letchford and D. Coopersmith. 1999. Effects of Spacing Paper Birch-Mixedwood Stands in Central British Columbia. B.C. Ministry of Forests, Research Program, Victoria, B.C. FRBC Project HQ96423-RE (MOF EP 1193).

Constabel, A.J. and V.J. Lieffers. 1996. Seasonal patterns of light transmission through boreal mixedwood canopies. Can. J. For. Res. 26: 1008-1014.

Day, T.A., E.H. DeLucia and W.K. Smith. 1990. Effect of soil temperature on stem sap flow, shoot gas exchange and water potential of Picea engelmannii (Parry) during snowmelt. Oecologia 84: 474-481. DeLucia, E.H. and W.K. Smith. 1987. Air and soil temperature limitations on photosynthesis in Engelmann spruce during summer. Can. J. For. Res. 17: 527-533.

Drew, T.J. 1988. Managing white spruce in Alberta's mixedwood forest: the dilemma. In J.K. Samoil (ed.). Management and Utilization of Northern Mixedwoods. pp. 35-40. Can. For. Serv. Info. Rep. NOR-X-296.

Eis, S. 1967. Establishment and early development of white spruce in the interior of British Columbia. For. Chron. 43: 174-177.

Eis, S. 1970. Root growth relationships of juvenile white spruce alpine fir, and lodgepole pine on three soils in the interior or British Columbia. Can. For. Serv. Publ. No. 1276.

Enns, K.A., E.B. Peterson and D. McLennan. 1993. Impacts of hardwood management on British Columbia wildlife: problem analysis. B.C. Ministry of Forests and Forestry Canada, Victoria, B.C. FRDA Rep 208. 78 p.

Gill, D.S., J.S. Amthor and F.H. Bormann. 1998. Leaf phenology, photosynthesis and the persistence of saplings and shrubs in a mature northern hardwood forest. Tree Physiol. 18: 281-289.

Green, D.S. 1998. Interrelation of leaf structure and function among deciduous broad-leaved and evergreen needle-leaved trees in southern Wisconsin. Ph.D. Dissertation, Univ. of Wisconsin, Madison. $95 \mathrm{p}$.

Green, D.S. Spruce growth under varying levels of paper birch competition differs on opposing slope aspects in the Sub-Boreal Spruce zone in central British Columbia. For. Ecol. Man. In Review. Green, D.S., J.E. Erickson and E.L. Kruger. 2003. Foliar morphology and canopy nitrogen as predictors of light-use efficiency in terrestrial vegetation. Ag. For. Meteorol. 115: 163-171.

Harper, G. and R. Kabzems. 2003. Growing-space management in boreal mixedwood forests - the establishment of EP 1192.01, Fort Nelson River site. B.C. Ministry of Forests, Victoria, B.C. Extension Note 64.8 p.

Holbo, H.R., S.W. Childs and D.H. McNabb. 1985. Solar radiation at seedling sites below partial canopies. For. Ecol. Man. 10: 115-124. Huxman, T.E., A.A. Turnipseed, J.P. Sparks, P.C. Harley and R.K. Monson. 2003. Temperature as a control over ecosystem $\mathrm{CO}_{2}$ fluxes in a high-elevation, subalpine forest. Oecologia 134: 537-546.

Jobidon, R. 2000. Density-dependent effects of the northern hardwood competition on selected environmental resources and young white spruce (Picea glauca) plantation growth, mineral nutrition and stand structural development: A 5-year study. For. Ecol. Man. 130: 77-97. Jurik, T.W., G.M. Briggs and D.M. Gates. 1988. Springtime recovery of photosynthetic activity of white pine in Michigan. Can. J. Bot. 66: 138-141.

Kabzems, R. and O. Garcia. 2004. Structure and dynamics of trembling aspen-white spruce mixed stands near Fort Nelson, BC. Can. J. For. Res. 34: 384-395.

Kabzems, R. and J.D. Lousier. 1992. Regeneration, growth and development of Picea glauca under Populus spp. Canopy in the boreal white and black spruce zone. Canada-British Columbia partnership agreement on forest resource development. FRDA Report 176. 35 p.
Kelty, M.J. 1992. Comparative productivity of monocultures and mixedspecies stands. In M.J. Kelty, B.C. Larson and C.D. Oliver (eds.). The Ecology and Silviculture of Mixed-Species Forests. pp. 125-141. Kluwer Academic Publishers, Boston.

Klinka, K., Q. Wang, G.J. Kayahara, R.E. Carter and B.A. Blackwell. 1992. Light-growth response relationships in Pacific silver fir (Abies amabilis) and subalpine fir (Abies lasiocarpa). Can. J. Bot. 70: 1919-1930.

Kobe, R.K. 1996. Intraspecific variation in sapling mortality and growth predicts geographic variation in forest composition. Ecol. Monogr. 66: 181-201.

Kobe, R.K. and K.D. Coates. 1997. Models of sapling mortality as a function of growth to characterize interspecific variation in shade tolerance of eight tree species of northwestern British Columbia Can. J. For. Res. 27: 227-236.

Krasowski, M.J. and D.G. Simpson. 2001. Frost-related problems in the establishment of coniferous forests. In F.J. Bigras and S.J. Colombo (eds.). Conifer Cold Hardiness. pp. 253-285. Kluwer Academic Publishers, Boston.

Laitakari, E. 1934. The root system of birch. Acta. For. Fenn. 41: 1-216. Lamontagne, M., H. Margolis and F. Bigras. 1998. Photosynthesis of black spruce, jack pine and trembling aspen after artificially induced frost during the growing season. Can. J. For. Res. 28: 1-12.

Landhäusser, S.M., R.W. Wein and P. Lange. 1996. Gas exchange and growth of three arctic treeline tree species under different soil temperature and drought preconditioning regimes. Can. J. Bot. 74: 686-693.

Landhäusser, S.M. and V.J. Lieffers. 1998. Growth of Populus tremuloides in association with Calamogrostis canadensis. Can. J. For. Res. 28: 396-401.

Landhäusser, S.M., A. DesRochers and V.J. Lieffers. 2001. A comparison of growth and physiology in Picea glauca and Populus tremuloides at different soil temperatures. Can. J. For. Res. 31: 1922-1929.

Landhäusser, S.M., U. Silins, V.J. Lieffers and W. Liu. 2003. Response of Populus tremuloides, Populus balsamifera, Betula papyrifera and Picea glauca seedlings to low soil temperature and water-logged soil conditions. Scan. J. For. Res. 18: 391-400.

Lieffers, V.J. and K.J. Stadt. 1994. Growth of understory Picea glauca, Calamagrostis canadensis and Epilobium angustifolium in relation to overstory light transmission. Can. J. For. Res. 24: 1193-1198. Lieffers, V.J., B. Pinno and K.J. Stadt. 2002. Light dynamics and free-to-grow standards in aspen-dominated mixedwood forests. For. Chron. 78(1): 137-145.

Loehle, C. 1998. Height growth rate tradeoffs determine northern and southern range limits for trees. J. Biogeog. 25: 735-742.

Logan, K.T. 1969. Growth of tree seedlings as affected by light intensity: IV. Black spruce, white spruce, balsam fir and eastern white cedar. Canadian Forestry Service. Ottawa, Ont. Publication 1256.

MacIsaac, D.A. and S. Navratil. 1996. Competition dynamics in juvenile boreal hardwood-conifer mixtures - silviculture of temperate and boreal broadleaf-conifer mixtures. In P.G. Comeau and K.D. Thomas (eds.). Land management handbook \#36. pp. 23-34. B.C. Ministry of Forests Research Program. Victoria, B.C.

Man, R. and V.J. Lieffers. 1997a. Seasonal variations of photosynthetic capacities of white spruce (Picea glauca) and jack pine (Pinus banksiana) saplings. Can. J. Bot. 75: 1766-1771.

Man, R. and V.J. Lieffers. 1997b. Seasonal photosynthetic responses to light and temperature in white spruce (Picea glauca) seedlings planted under an aspen (Populus tremuloides) canopy and in the open. Tree Physiol. 17: 437-444.

Man, R. and V.J. Lieffers. 1999. Are mixtures of aspen and white spruce more productive than single species stands? For. Chron. 75: 505-513.

McComb, W.C. 1994. Red alder: interactions with wildlife. In D.E. Hibbs, D.S. DeBell and R.F. Tarrant (eds.). The biology and management of red alder. pp. 131-137. Oreg. State Univ. Press, Corvallis, Oregon. 
Messier, C. 1996. Managing light and understory vegetation in boreal and temperate broadleaf-conifer forests. In P.G. Comeau and K.D. Thomas (eds.). Silviculture of temperate and boreal broadleafconifer mixtures. pp. 59-81. B.C. Ministry of Forests, Victoria, B.C. Messier, C., R. Doucet, J.C. Ruel, Y. Claveau, C. Kelly and M.J. Lechowicz. 1999. Functional ecology of advance regeneration in relation to light in boreal forests. Can. J. For. Res. 29: 812-823.

Mielikainen, K. 1985. Effect of an admixture of birch on the structure and development of Norway spruce stands. Commun. Inst. For. Fenn. 133:1-79.

Mielikainen, K. 1996. Approaches to Managing Birch-dominated Mixed Stands in Finland. In P.G. Comeau and K.D. Thomas (eds.). Silviculture of Temperate and Boreal Broadleaf-conifer Mixtures. Land Management Handbook \#36. pp. 8-14. B.C. Ministry of Forests, Research Program, Victoria, B.C.

Monteith, J.L. 1972. Solar radiation and productivity in tropical ecosystems. J. Appl. Ecol. 9: 747-766.

Morrison, D., G.W. Wallis and L.C. Weir. 1988. Control of Armillaria and Phellinus root diseases: 20-year results from Skimikin stump removal experiment. Can. For. Serv. Pac. For. Cent. Victoria, B.C., Inf. Rep. BC-X-302.

Morrison, D., H. Merler and D. Norris. 1991. Detection, recognition and management of Armillaria and Phellinus root disease in the southern interior of British Columbia. B.C. Ministry of Forests and Forestry Canada, Victoria, B.C. FRDA Rep. 179. 25 p.

Myking, T. and O.M. Heide. 1995. Dormancy release and chilling requirement of buds of latitudinal ecotypes of Betula pendula and B. pubescens. Tree Physiol. 15: 697-704.

Navratil, S. 1996. Sustained aspen productivity on hardwood and mixedwood sites. In P.G. Comeau, G.H. Harper, M.E. Blache, J.O. Boateng and K.D. Thomas (eds.). Ecology and management of B.C. hardwoods pp. 53-64. B.C. Ministry of Forests, Research Branch. FRDA Report 255.

Öquist, G. 1983. Effects of low temperature on photosynthesis. Plant Cell Environ. 6: 281-300.

Parent, S. and C. Messier. 1995. Effets d'un gradient de lumière sur la croissance en hauteur et la morphologie de la cime du sapin baumier régénéré naturellment. Can. J. For. Res. 25: 878-885.

Peterson, E.B. and N.M. Peterson. 1996. Ecology and silviculture of trembling aspen. In P.G. Comeau, G.H. Harper, M.E. Blache, J.O. Boateng and K.D. Thomas (eds.). Ecology and management of B.C. hardwoods. pp. 31-64. B.C. Ministry of Forests, Research Branch. FRDA Report 255.

Pinno, B.D., V.J. Lieffers and K.J. Stadt. 2001. Measuring and modeling the crown and light transmission characteristics of juvenile aspen. Can. J. For. Res. 31: 1930-1939.

Prescott, C.E., L.M. Zabek, C.L. Staley and R.D. Kabzems. 2000. Decomposition of broadleaf and needle litter in forests of British Columbia: influences of litter type, forest type and litter mixtures. Can. J. For. Res. 30: 1742-1750.

Prévost, M. and D. Pothier. 2003. Partial cuts in a trembling aspenconifer stand: effects of microenvironmental conditions and regeneration dynamics. Can. J. For. Res. 33: 1-15.

Sachs, D.L. 1996. Simulation of the growth of mixed stands of Douglas-fir and paper birch using the FORECAST model. In P.G. Comeau and K.D. Thomas (eds.). Silviculture of temperate and boreal broadleaf-conifer mixtures. Land Management Handbook \#36. pp. 152-158. B.C. Ministry of Forests, Research Program, Victoria, B.C

Shirley, H.L. 1945. Reproduction of upland conifers as affected by root competition and light. Am. Midl. Nat. 33: 537-612.

Simard, S. 1990. A retrospective study of competition between paper birch and Douglas-fir. B.C. Min. For. FRDA Rep. 147. 19 p. Simard, S. 1996. Mixtures of paper birch and conifers: An ecological balancing act. In P.G. Comeau and K.D. Thomas (eds.). Silviculture of temperate and boreal broadleaf-conifer mixtures. Land Management Handbook \#36. pp. 15-22. B.C. Ministry of Forests, Research Program, Victoria, B.C.
Skre, O. 1993. Growth of mountain birch (Betula pubescens Ehrh.) in response to changing temperature. In J. Alden, J.L. Mastrontonio and S. Ødum (eds.). Forest Development in Cold Climates. pp. 65-78. Plenum Press, New York.

Steele, T.W., S.M. Nykoluk and C.D.B. Hawkins. 2001. Economics of birch management: Placing a value of mixedwood silviculture. Proceedings of the Paper Birch Workshop and Conference. September 19-22, 2001. University of Northern British Columbia, Prince George, B.C.

Stewart, J.D., S.M. Landhäusser, K.J. Stadt and V.J. Lieffers. 2001. Predicting natural regeneration of white spruce in boreal mixedwood understories. For. Chron. 77: 1006-1013.

Stathers, R.J. 1989. Summer frost in young forest plantations. FRDA Rep. 73. For. Can. and BC Min. For. Res. Branch, Victoria, B.C.

Strong, W.L. and G.H. La Roi. 1983. Root-system morphology of common boreal forest trees in Alberta, Canada. Can. J. For. Res. 13: 1164-1173.

Tanner, D., S.C. DeLong and A. Eastham. 1996. Investigations of planting white spruce under a trembling aspen canopy. In P.G Comeau and K.D. Thomas (eds.). Silviculture of temperate and boreal broadleaf-conifer mixtures. Land Management Handbook \#36. pp. 114-121. B.C. Ministry of Forests, Research Program, Victoria, B.C.

Taylor, S.P., R. Alfaro, C. Delong and L. Rankin. 1994. The effects of overstory shading on pine weevil damage to interior white spruce. In R.I. Alfaro, G. Kiss and R.G. Fraser (eds.). The white pine weevil: Biology, damage and management. Proc. Symp. Jan. 19-21, 1994, Richmond, B.C. pp. 254-261. Canadian Forest Service and B.C. Ministry of Forests, Victoria, B.C. FRDA Rep. 226.

Teskey, R.O., T.M. Hinckley and C.C. Grier. 1984. Temperatureinduced change in the water relations of Abies amabilis (Dougl.) Forbes. Plant Physiol. 74: 77-80.

Tryon, P.R. and F.S. Chapin. 1983. Temperature control over root growth and biomass in taiga forest trees. Can. J. For. Res. 13: 827-833.

Turner, N.C. and P.G. Jarvis. 1975. Photosynthesis in Sitka spruce (Picea sitchensis [Bong.] Carr.) IV. Response to soil temperature. J. Appl. Ecol. 12: 561-576.

Valkonen, S. and L. Valsta. 2001. Productivity and economics of mixed two-storied spruce and birch stands in Southern Finland simulated from empirical models. For. Ecol. Man. 140: 133-149.

Valkonen, S. and J. Ruuska. 2003. Effect of Betula pendula admixture on tree growth and branch diameter in young Pinus sylvestris stands in southern Finland. Scan. J. For. Res. 18(5): 416-426.

Van Cleve, K., L.K. Oliver, R. Schlentner, L.A. Viereck and C.T. Dyrness. 1983. Productivity and nutrient cycling in taiga forest ecosystems. Can. J. For. Res. 13: 747-766.

Viereck, L.A. 1970. Forest succession and soil development adjacent to the Chena River in interior Alaska. Arct. Alp. Res. 2: 1-26.

Wang, J.R. and J.P. Kimmins. 2002. Height growth and competitive relationship between paper birch and Douglas-fir in coast and interior British Columbia. For. Ecol. Man. 165: 281-289.

Wang, J.R., S.W. Simard and J.P. Kimmins. 1995. Physiological responses of paper birch to thinning in the ICHmw subzone of British Columbia. For. Ecol. Man. 73: 177-184.

Waring, R.H. and W.H. Schlesinger. 1985. Forest Ecosystems: Concepts and Management. Academic Press, New York.

Watt, A.D. 1992. Insect pest population dynamics: effects of tree species diversity. In M.G.R. Cannell, D.C. Malcom and P.A. Robertson (eds.). The ecology of mixed-species stands of trees. Br. Ecol. Soc. Spec. Publ. 11. University Press, Cambridge, U.K.

Wright, E.F., K.D. Coates, C.D. Canham and P. Bartemuccii. 1998. Species variability in growth response to light across climatic regions in northwestern British Columbia. Can. J. For. Res. 28: 871-886.

Yang, Y., S.J. Titus and H. Shongming. 2003. Modeling individual tree mortality for white spruce in Alberta. Ecol. Mod. 163: 209-222. 